J. Perinat. Med.

1 (1973) 263

\title{
Time determination of the occurrence of meconium staining of amniotic fluid during the last weeks of normal pregnancy
}

\author{
J. Vuji ć \\ Department of Gynecology and Obstetrics, General Hospital "Dr. O. \\ Novosel", Zagreb, Yugoslavia
}

Received July 13, 1972. Accepted November 3, 1972.

Since the first report by SALING in 1962 of the amnioscopic method, over 200 articles have been published dealing with this technique. Results obtained with the amnioscopic method have been compared with those from urinary estrogen determinations [3], fetal ECG monitoring [2] and amniocentesis [10]. Topics such as associated morbidity in parturient and fetus [12], infection of fetal membranes [5], appearance of misleading findings [11], evaluation of doubtful findings [9] and the limitations of the amnioscopic method [6] have been discussed. Further related publications have included an explanation for the possible appearance and elimination of meconium from the amniotic fluid [10], a report of experiences with attempted modifications of the method, as well as utilizing hysteroscopy in pregnancy [1], descriptions of applying the colposcope and cold light $[4,7]$ and the modified hysteroscope in amnioscopic research [14].

Drawing upon the studies mentioned above and our own favorable experience with over 3,500 amnioscopic examinations, our interest has been directed towards a further evaluation of the amnioscopy. This has resulted in an examination of the frequency with which meconium staining of the amniotic fluid is found at the onset of labor in cases of normal pregnancy [13]. Of 536 parturients studied at the onset of labor after completely normal pregnancies. 7 cases or $1.3 \%$ were found to have meconium-stained amniotic fluid. This is in contrast to $\mathbf{7 - 8} \%$ found in cases of high risk pregnancy where fetal hypoxia was to be expected. Analysis of these data concerning meconium staining of the amniotic fluid at the onset of labor has shown that there

\section{Curriculum vitae}

Jovan Vujré, $M$. D., doctor of science, assistent professor, specialist in g'necolog' and obstetrics, was born in 1925 in Sombor, Yugoslavia. He studied medicine in Prague and Zagreb, graduating from the Medical Scbool of Zagreb in 1952. He specialized in ginecology' in Zagreb from 1955 to 1959, and did postgraduate

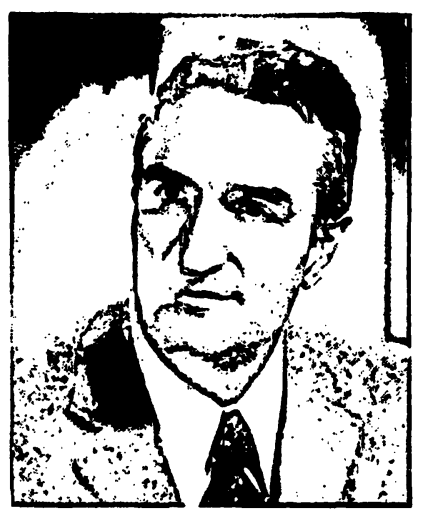
work in specific areas of ob-

stetrics at Göteborg, Berlin and Vienna. The title of Dcctor of Science in Gynecolog)' and Obstetrics was awarded in 1964. Since 1959, be bas been Cbief of Obstetrics, Department of Gynecology and Obstetrics, General Hospital "Dr. O. Novosel", Zagreb, Yugoslavia.

Dr. Vijić's specific fields of interest and research include: vacunm extraction and its sequelae, the fetus at risk, amnioscopy, $p H$ measurement, amniotic fuid examination, ultrasound.

exist possible causes for the appearance of meconium in spite of the lack of obvious clinical manifestations.

In the present study, we have extended our interest to include the amnioscopic determination of the time of possible occurrence of meconium staining during the last weeks of normal pregnancy.

\section{Subjects and Methods}

Amnioscopic examination of the amniotic fluid was carried out twice a week on 362 parturients during the last four weeks of pregnancy. In 32 of the 362 subjects, delivery was carried out $8-10$ days prior to the expected date of confinement, hence the amnioscopic examinations were carried 
out during a 3 week period only. The parturients included primiparae and multiparae between the ages of 22 and 30, and all had normal pregnancies. Routine studies were normal in all cases, and there was no infection, toxemia, etc.; none of the subjects smoked or consumed alcohol. Tests for urinary albumin were negative or only slightly opalescent, and blood pressures ranged between $120 / 80$ and $140 / 90$.

For the purpose of comparison, an analysis of complications in 100 parturients receiving amnioscopy was compared with that of a corresponding control group of non-amnioscopized patients.

\section{Results}

Of the 362 subjects in the series, 156 were primiparae and 206 were multiparae. Delivery came within 3-5 days of term in 319 subjects, or $88 \%$, and within 8-12 days of the expected date of confinement in 43 subjects, or $12 \%$.

Tab. I characterizes the amnioscopic examinations, and Tab. II reflects the amnioscopic findings in a total of 1602 amnioscopies performed during the last 3-4 weeks of normal pregnancy.

Tab. I. Amnioscopic examinations.

\begin{tabular}{cccc}
\hline $\begin{array}{c}\text { Last } \\
\text { weeks of } \\
\text { pregnancy }\end{array}$ & $\begin{array}{c}\text { No. of } \\
\text { examinations } \\
\text { per week }\end{array}$ & $\begin{array}{c}\text { No. of } \\
\text { subjects }\end{array}$ & $\begin{array}{c}\text { No. of } \\
\text { examinations }\end{array}$ \\
\hline 4 & 1 & 287 & 1148 \\
4 & 2 & 32 & 258 \\
3 & 1 & 20 & 60 \\
3 & 2 & 23 & 138 \\
\hline Total: & & 362 & 1602 \\
\hline
\end{tabular}

Tab. II. Amnioscopic findings.

\begin{tabular}{lrrrr}
\hline Weeks of pregnancy & 37 & 38 & 39 & 40 \\
\hline $\begin{array}{l}\text { Subjects with normal findings } \\
\begin{array}{l}\text { Subjects with meconium-stained } \\
\text { amniotic fluid }\end{array}\end{array}$ & 362 & 362 & 361 & 319 \\
\hline
\end{tabular}

\section{Comment}

The results of our previous research on the presence of meconium-stained amniotic fluid indicate a frequency of $1.3 \%$ at the onset of labor in normal pregnancy. However, with the onset of labor and the initial contractions, there is a change in the relation' between stasis and the hemodynamics of the uterus, and this must be taken into consideration. The ratio between amnioscopically determined meconium-stained amniotic fluid in normal pregnancy and that found in cases of increased risk of fetal distress and hypoxia at the onset of delivery is $1.3 \%: 7-8 \%$.

This difference in frequency between normal and abnormal pregnancies is even more accentuated when comparing the results obtained during our current study dealing with the time of appearance of meconium-stained amniotic fluid in the last 4 weeks of normal pregnancy. The method of amnioscopy is shown to be a very reliable indication of the intrauterine state of the fetus and a means of detecting early changes.

The presence of meconium-stained amniotic fluid in one of the above mentioned cases and its disappearance one week prior to delivery was verified by transabdominal amniocentesis. In 5 other cases where the amnioscopic findings were doubtful; amniocentesis demonstrated the fluid to be clear, and this was proven at the time of the rupture of the membranes. The phenomenon of the occurrence and then the subsequent elimination of meconium from the amniotic fluid has already been demonstrated to be possible and has been explained by SALING and Schriever [10]. All amnioscopic findings in our subjects were confirmed before delivery by means of amniocentesis.

The results of this study confirm the fact that the presence of meconium-stained amniotic fluid is extremely rare under conditions of normal pregnancy. Thus, the appearance of meconium in the amniotic fluid is consistently related to fetal distress, and its determination may nearly always serve as a reliable and valuable indicator of changes in the normal intrauterine fetal state.

The necessity of carrying out frequent amnioscopic examinations during this study did not lead to increased parturient morbidity in terms of mechanical injuries, local infection or inflammation, intrauterine infection, premature rupture of membranes or early delivery. There were no essential differences in frequency of such complications when comparing groups of 100 amnioscopized and non-amnioscopized women with normal pregnancies. 


\section{Conclusions}

'I he results of these studies demonstrate that meconium very rarely appears in the amniotic fluid of normal pregnancies, and when it does it generally occurs in the last $1-2$ weeks prior to delivery. The phenomenon of the appearance and the subsequent disappearance of meconium in the amniotic fluid has been confirmed. Amnioscopic examination of the amniotic fluid is shown to yield rcliable conclusions and to be capable of detccting changes in the intrauterine state of the fetus as regards distress due to hypoxia. It has proven to be a suplementary, simple and reliable method of assessing the intrauterine state of the fetus in late pregnancy before the membranes have ruptured.

\section{Summary}

The problem of the validity of meconium-staining of the amnintic fluid as a sign of fetal distress, and the evaluation of amnioscopy as a simple and harmless method of determining intrautcrinc changes in fetal state have led us tos study the frequency of appearance of meconiumstained amniotic fluid in normal pregnancy as well as the time of its appearance during the last weeks of normal pregnancy.

To this end we have carricd out amnioscopic examinations 1-2 times weekly on 362 parturicnts during the last 3-4 wecks of pregnancy. Both primiparac and multiparac werc used as subjects, and their age-range was between 22 and 33. All pregnancies were considered normal on the basis of the results of prenatal examinations, absenec of infection, toxemia and other disturbances, and normal urine and blood pressure values.

A total of 1602 amnioscopic examinations were carried out on 362 parturients, and only one case of meconiumstained amniotic fluid was identified (Tabs. I and II).

This was confirmed by amniocentesis 2 wecks prior to delivery. In five other cases the results of amniocospy were doubtful, but the fluid proved to be normal when amniocentesis was carried out. All findings were verified by amniocentesis prior to delivery.

There was no increased frequency of morbidity in the form of mechanical injury, local or intrauterinc infection, carly delivery or premature rupture of membrancs in the study group as compared with non-amninecopized contersl parturients.

The results demonstrate that passage of meconium into the amniotic fluid is a rare occurrence in normal pregnancy, takes place during the last $1-2$ wecks beforc delivery, and represents a valuable sign of intrauterine fetal distress when it docs occur. Amnioscopy has proven to be a simple yet sure method of prenatal examination and a most helpful supplementary methed in assessing the intrautcrine state of the fetus in cases where the membrancs have not yet ruptured.

Keywords: Amnioscopy, meconium (determination of timc), pregnancy (normal), amniotic fluid.

\section{Zusammenfassung}

Zeitpunkt des Auftretens mekoniumhaltigen Fruchtwassers in den letzten Wochen der ungestörten Schwangerschaft.

Die Frage nach der Zuverlässigkeit des Auftretens von Mekonium als Zcichen eincr intrauterinen Beeinträchtigung des Feten, und dementsprechend dic Uberprüfung der Amnioskopie als cine einfache und unschädliche Methode zur. Feststellung der genannten Störung veranlaßten uns, amnioskopisch cin eventuelles Auftreten mekoniumhaltigen Fruchtwassers bei ungestörten Schwangerschaften zu untersuchen und den Zeitpunkt seines Auftretens in den letzten Wochen der Schwangerschaft festzustellen.

Hicr»u führten wir dic amnioskopische Untersuchung auf mekoniumbaltiges Fruchtwasser cin- bis zweimal pro Woche an 362 Schwangeren in den letzten vier Schwangerschaftswochen durch. 32 der 362 Schwangeren wurden nur in den letzten drei Schwangerschaftswochen amnioskopiert, da es frühct zur Gchurt kam. Es handclte sich um Erst- und
Mehrgebärende, alle mit ungestörter Schwangcrschaft, zwischen 22 und 30 Jahre alt, mit normalen Ergebnissen bei den Schwangerschaftsuntersuchungen ohne irgend einc Störung, Infektion oder Gestosc, sic waren Nichtraucher und nahmen keinen Alkohol \%u sich (mit normalen Urinbefunden und Blutdruckwerten «wischen 120/80 und 140/90).

Es wurden 1602 Amnioskopien durchgeführt, und nur ein einziger Fall mit mekoniumhaltigem Fruchtwasser trat bei den 362 Schwangeren auf, was zwei Wochen vor der Entbindung durch Amniozentese gesichert wurde (Tab. I und II). Unter den Normalfällen waren fünf wcitcre amnioskopisch unklare Fälle; dic Amnio\%cntesc bestätigte aber normale Verhältnisse. Alle Untersuchungsergebnisse wurden vor der Entbindung durch Amniozentese gesichert.

Dic Häufigkeit der Amnioskopien in unsercr Studic führte auch in der Morbidität bezüglich mechanischer Verletzungen, lokaler und intrauteriner Infektionen, voreceitiger Ge- 
burt und vorzeitigem Blasensprung zu keinem wesentlichen Unterschied gegenüber den festgestellten Veränderungen bei den nicht amnioskopierten Schwangeren der Kontrollgruppe. Die Ergebnisse zeigten, daß Mekonium nicht im Fruchtwasser von Schwangeren mit ungestörter Schwangerschaft auftritt, mit Ausnahme sehr seltener Fälle und hier in den letzten ein bis zwei Wochen vor der
Entbindung, was das Auffinden von Mekonium als ein wertvolles Zeichen zur Erkennung einer intrauterinen Beeinträchtigung des Feten erweist, wobei sich die Amnioskopie als eine einfache und sehr zuverlässige Methode bei der komplizierten Erforschung des intrauterinen Zustandes des Feten bei noch intakten Eihäuten bewährt hat.

Schlüsselwörter: Amnioskopie, Mekonium (Zeitpunktbestimmung), Schwangerschaft (ungestörte), Fruchtwasser.

\section{Résumé}

Le moment de l'apparition de méconium dans le liquide amniotique au cours des dernières semaines de gestation normale.

Afin de déterminer la valeur de l'apparition de méconium dans le liquide amniotique comme signe de souffrance foetale, et d'évaluer les possibilités de la diagnostiquer de façon simple et anodine, nous nous sommes intéréssés à l'amnioscopie au cours des dernières semaines de gestation.

Dans ce but, nous avons pratiqué cet examen une à deux fois par semaine au cours du dernier mois de la grossesse. Notre travail a porté sur 362 patientes, parmi celles ci 32 ne furent suivies que durant 3 semaines du fait qu'elles accouchèrent plus tôt que prévu. Notre population était composée de primipares et de multipares agées de 22 à 30 ans, dont la grossesse avait été strictement normale: paramètres obstétricaux normaux, absence d'infection et de toxémie; aucune de nos patientes ne fumaient ni ne buvaient. Les examens urisaires avaient toujours été normaux, et la tension artérielle était comprise entre $120 / 80$ et $140 / 90$.
Un liquide méconial fut obṣervé une seule fois sur 1602 amnioscopies pratiquées chez nos 362 parturientes (Tab. I et II), et ce résultat fut vérifié par amniocentèse 2 semaines avant l'accouchement.

La morbidité provoquée par traumatisme, infections locales ou intra-utérines, accouchement prématuré ou rupture intenpestive des membranes ne présenta aucune différence significative entre les cās soumis à des amnioscopies répétées et le groupe de contrôle n'ayant subi aucune amnioscopie.

Les résultats obtenus ont montré que l'apparition de méconium dans le liquide amniotique au cours des deux dernières semaines de gestation est ràrissime lorqu'il s'agit de grossesse normale.

L'apparition d'un liquide teinté constitue donc un bon signe diagnostic de souffrance foetale. L'amnioscopie s'est avérée un moyen simple et fidèle d'évaluation de l'état foetal avant la rupture des membranes.

Mots-clés: Amnioscopie, Méconium, grossesse normale, liquide amniotique.

\section{Bibliography}

[1] Agüere, E., M. Aure, R. Popez: Hysteroscopy in pregnant patients - a new diagnostic tool. Amer. J. Obstet. Gynec. 94 (1966) 925

[2] Bolte, A., H. Bauerschmitz: Amnioskopie, Zervixbefund und Geburtseinleitung bei Verdacht auf $\mathrm{Pla}$ zentadysfunktion nach Selektion durch fetale Elektrokardiographie. Geburtsh. u. Frauenheilk. 29 (1969) 578

[3] Erkrath, F. A., H. Randow: Gesamtoestrogene im Harn bei positiver Amnioskopie und Úbertragung. Dtsch. Gesundheitswesen 21 (1966) 552

[4] Hoffbauer, H., P. Carsten: Die Spiegelung des unteren Eipoles unter Verwendung des Kolposkopes. Geburtsh. u. Frauenheilk. 24 (1964) 771

[5] Herky, Z., K. Amon: Rundzelluläre Infiltrationen der Eihäute nach Amnioskopie. Geburtsh. u. Frauenheilk. 27 (1967) 1065

[6] Horky, Z., G. Lorenz: Totgeburt ohne Mekoniumabgang. Zbl. Gynäk. 91 (1969) 791
[7] Kress, D., F. W. DittmaR: Erfahrungen mit der Kaltlicht-Amnioskopie. Z. Geburtsh. Gynäk. 166 (1967) 311

[8] Kubli, F.: Fetale Gefahrenzustände und ihre Diagnose. Thieme, Stuttgart 1966

[9] KubLI, F.: The optical evaluation of amniotic fluid. In: Húntingford, P. J., K. A. Hüter, E. SAling: Perinatal Medicine. 1st European Congress of Perinatal Medicine, Berlin, 26th-30th March 1968. Thieme, Stuttgart 1969

[10] Saling, E., J. Schriever: Nachweis einer Mekoniumelimination aus dem Fruchtwassser. Geburtsh. u. Frauenheilk. 27 (1967) 585

[11] Teramo, K.: Selected Observations on Amnioscopy. In: Huntingford, P. J.; K. A. Hüter, E. SAling: Perinatal Medicine. 1st European Congrèss of Perinatal Medicine, Berlin, 26th-30th March 1968. Thieme, Stuttgart 1969 
[12] Trtrler, W.: Untersuchungen über die Morbidität nach Amnioskopie. Dissertation, Berlin 1964

[13] Vujrć, J.: Amnioscopic determination of occurrences of meconial fluid for no obvious reasons at the onset of delivery. In: Horsky, J., Z. K. STEmbera: Intrauterine dangers to the foetus. Excerpta Medica Foundation, Amsterdam 1967
[14] Vujrć, J.: Möglichkeiten der amnioskopischen Prüfung des Fruchtwassers mit Kaltlicht-Amnioskop und modifiziertem Hysteroskop. In: Saling, E., J. W. Dudenhausen: Perinatale Medizin, Band III. 4. Deutscher Kongreß für Perinatale Medizin. Berlin, 4. bis 6. Nov. 1971. Thieme, Stuttgart 1972

Doc. Dr. Sc. J. Vujić

Department of Gynaecology and Obstetrics, General Hospital "Dr. O. Novosel", Zajčeva 19,

41000 Zagreb, Yugoslavia 